\title{
BÁSNÍK A PŘEKLADATEL JIŘí KOVTUN
}

\author{
LUKÁŠ KLIMEŠ
}

\begin{abstract}
The aim of this article is to discuss the role of Jiři Kovtun, a Czech writer and historian, in the development of Czech translatology. It is based on the article Čapek's translations in the development of Czech translatology and verse by Jiři Levý, which serves as the theoretical-methodological basis. Although his work is not extensive, Kovtun's translations are of importance: in the context of his translation of The Poems of Doctor Zhivago, published by an exile publisher Svědectví, we tried to demonstrate the character of Kovtun's translation method and how his creative process and the selection of authors to translate were influenced by the fact that he himself was a poet. The conclusion is that Kovtun's translations are accurate in the technical sense but often lose track of the original and bring elements of the translator's own poetic idiolect into the translated poems.
\end{abstract}

Key words: Jiří Kovtun, Czech translation of The Poems of Doctor Zhivago, Jiří Levýs methodology, Čapek’s translations

Roku 1971 v ediční péči Miroslava Červenky vyšel in memoriam soubor literárněvědných a translatologicky orientovaných studií Jiř́iho Levého (1926-1967), eminentního českého teoretika překladu a literárního historika, pod názvem Bude literární věda exaktní vědou?. Tento rozsáhlý výbor obsahuje podnětnou studii Čapkovy preklady ve vývoji českého překladatelství a českého verše, v níž se Levý (1971: 227-268) zaobírá převody francouzských básníků českého intelektuála Karla Čapka (1890-1938), otištěných ve Francouzské poesii nové doby (1920). V této souvislosti Levý nastiňuje, jak při obdobných hodnoceních postupovat a jak získat oporu pro následná uvažování: postupně zasazuje Čapkovy překlady do literárněhistorického vývoje českého překladatelství, erudovaným komentářem opatřuje překlady „jeho“ básníků a současně se snaží určit Čapkův podíl na proměně českého básnického jazyka.

$\mathrm{Na}$ Levého studii lze nahlížet jako na inspirační teoreticko-metodologický koncept, jejž můžeme aplikovat i na jiné tuzemské překladatele básnických textů, kteří se svým vlastním způsobem zasadili o rozvoj převodů cizojazyčných literátů do češtiny.

Za literáta, na jehož odkaz uplatníme Levého metodologii a jehož osobu se pokusíme vřadit do př́slušného dobového kontextu, jsme zvolili básníka, překladatele a historika Jiřího Kovtuna (1927-2014), rodáka z ukrajinského Horinčeva. Pro lepší pochopení 
souvislostí mezi Kovtunovou tvorbou a jeho životním údělem, odrážející se v jeho díle, je třeba říci následující: po únorovém komunistickém puči byl, v té době již jako redakční tajemník týdeníku Vývoj, který založil jeho dlouholetý přítel Pavel Tigrid, vyloučen z vysokoškolských studií na pražské právnické fakultě, rovněž ze Syndikátu československých novinářu (Debnár 2006: 10) a v květnu téhož roku opustil Československo. Po tř́leté epizodě, kdy vystřídal nejrůznější zaměstnání, se usadil na redaktorském postu v rozhlasu Rádia Svobodná Evropa (RFE). Svou americkou anabázi zahájil na newyorské Graduate School of Library and Information Science na Prattově univerzitě studiem knihovnictví, přechodně pracoval jako žurnalista na volné noze, působil jako člen redakční rady Tigridova časopisu Svědectví a spolupracovník československého oddělení v rozhlasu Hlas Ameriky (Opat 1991: 522). Roku 1977 nastoupil jako knihovník-specialista ${ }^{1}$ na českou a slovenskou problematiku v Knihovně Kongresu USA ve Washingtonu, čímž mimo jiné získal přístup k archiváliím, z nichž těžil pro své historiografické studie. Myšlenku vrátit se natrvalo do České republiky uskutečnil po smrti své ženy Věry v roce 2009.2 2

V českém prostředí je Kovtun primárně vnímán jako erudovaný historik a vykladač Masarykova života a kontextu jeho díla: sledovat Kovtunovo uvažování nad významem prvního československého prezidenta můžeme kupř. v úvodní studii k prezidentovým projevům Slovo má poslanec Masaryk (1985), v monografii Masarykův triumf (1987) či v architektonicky orientované knize Pražský hrad za T. G. Masaryka (1995). Pomyslné završení historikova odborného zájmu představuje jeho životní dílo Republika v nebezpečném světě: éra prezidenta Masaryka, 1918-1935 (2005) a nedokončená, posmrtně vydaná Republika v obležení: první éra prezidenta Beneše (2016). Neméně významná je jeho literární činnost.

\section{Kovtun-básník}

Jiří Levý v úvodu své studie hodnotí stav českého poezie, do nějž roku 1920 vstupují Čapkovy převody, a uvádí, že tuzemské básnictví již překonalo symbolistní a dekadentní období, zažilo nástup mladšího básnického pokolení v čele s J. S. Macharem, V. Dykem a K. Tomanem a poněkud se vrací „zpět k básnickým tradicím 19. století.“ (Levý 1971: 227) Aby se vyjadřovací prostředky, jež vytvořili pro své vybrané cíle básníci poslední dekády 19. století, mohly stát „trvalou součástí dalšího vývoje k poezii poetistické, civilizační a proletářské,“ Levý dodává, že „bylo třeba uvést do české poezie básnický

1 Často se uvádí, že Kovtun pracoval jako knihovník v československém oddělení Kongresu. Tato informace je pravdivá pouze z části, srov. výpověd’ J. Kovtuna: „V Knihovně Kongresu není žádné takové české nebo československé oddělení. Věci, které se týkají Československa v mém oboru, obstarává European Division, neboli Evropské oddělení, což dř́ve bývalo oddělení Středoevropské, Východoevropské a Slovanské. Po reorganizaci se pak přetvořilo v oddělení celoevropské. Není to systém, že by každá země měla jednoho zvláštního specialistu, odborníci se člení spíš podle jazykově blízkých oblastí [...] Takže já jsem československý specialista v tomto Evropském oddělení, ale nejsem jediný česky nebo slovensky mluvící člověk v Knihovně Kongresu, ačkoli jich tam není mnoho, tak čtyři, pět a pracují na nejrůznějších úsecích." (Hájková, 1992, s. 15)

2 Citujeme dle vzpomínek překladatelovy dcery Karoliny Kovtun. 
typ, který v jejím vývoji chyběl. “ Na otázku, kde takový typ hledat, Levý glosuje Čapkovy názory na dobový stav poezie i na výběr jeho básníků.

Pokud bychom si chtěli vyslechnout Kovtunovy názory na obdobné téma, v patřičném kontextu české poezie, vyvstane před námi zásadní problém: Kovtun se k této problematice, alespoň nakolik se nám podařilo dohledat, př́liš nevyjadřoval. Z několika jeho úvah, porůznu otištěných v tuzemských i zahraničních periodikách, jsme zvolili následující citát, o němž se domníváme, že je charakteristický pro jeho tvorbu, a to nejen básnickou, ale i př̀kladovou:

„Př̌edstavte si, že píšu historii a hledám přesnější fakta. Vedle toho, co bezpečně - jak se domnívám - zjistím, jsou nejistoty, tajemství, nebezpečí. Čím více vím, tím si zároveň zvětšuji oblast toho, co nevím a nikdy vědět nebudu. Historie vás nutí k sókratovské skromnosti, anebo nejste historik. A představte si, že píšu poezii a hledám nejpřesnější, nejúčinnější slovo. To, co v básni snad dobře - jak se domnívám - vyjádřím, mi zase jen zvětšuje oblast skutečností a snů, kterou bych chtěl nějakým rozhodujícím slovem otevřít, ale nikdy neotevřu. Poezie vás nutí k františkánské pokoře, anebo nejste básník." (Hájková, 1991, s. 13)

Jaký básnický typ zosobňuje Jiří Kovtun? A jak mu pomáhá při výběru cizojazyčných básníků, jež chce přetlumočit českému publiku? Kovtunova básnická tvorba, rodící se souběžně s tvorbou překladatelskou, není co do rozsahu př́liš objemná: v roce 1953, po několika časopisecky otištěných básních, ${ }^{3}$ vyšel jeho spirituálně laděný soubor Blahoslavení, složený „z meditací na evangelijní pasáže o osmeru blahoslavenstvi“ (Putna, 2017, s. 316), a o rok později jeho jeho útlá sbírka nápodob čínské poezie Tu-Fuův žal. V následujících dekádách se Kovtun své básnické tvorbě př́liš nevěnoval ${ }^{4}$ a více se soustředil na psaní prózy. ${ }^{5}$ Svou pomyslnou básnickou cestu uzavřel kompilátem básní s názvem Hřbet velryby (1995), který spolu s rozšírenou verzí předchozí sbírky, tentokrát uvedenou jako Radosti a smutky básníka Tu Fu (!), obsahuje dosud nezveřejněné texty z 50.-70. let.

Podle literárního teoretika Jiřího Trávníčka se lze domnívat, že na základě edičního zacházení s básněmi v souboru Hřbet velryby Kovtun na svou vlastní poezii nahlížel jako na „uzavřený celek“ - spíš než na „vývojové zlomy a návaznosti“ se klade důraz na „vědomí integrity“. Jinými slovy, „celek je dán už prvními verši a ty další představují jen další a další jeho potvrzování." (Trávníček 1995: 20) K obdobnému závěru došel i Jan Štolba ve své recenzi na výše zmíněný soubor básní, když uvedl, že poezie je v Kovtunově tlumočení „myšlenkově celistvá“, „kultivovaná“, i „nenásilně originální, i přestože jeho básně vznikaly spíše nesoustavně, na okraji Kovtunovy tvorby (Štolba 1995: 7).

Svým výběrem křestanských, přírodních a spirituálně laděných motivů usiluje s onou „františkánskou pokorou“, o níž Kovtun mluví v rozhovoru pro Studentské listy, o „vyjá-

3 Kovtunovy juvenilní básně lze dohledat kupř. na stránkách časopisu Skutečnost (1951 3(8-9): 161, 167) či Sklizeň (1953 1(11): 1-2).

4 Jako básník se však neodmlčel nadobro. Jeho básně tvoří součást antologie básní českých exulantů Čas stavění (Vídeň: Bohemica Viennensia, 1956: 14-15) a rovněž je otisklo několik periodik, v čele s Archou (1958 1(1): 1-4), či Svědectvím (1962 5(18): 169-170; 1969 9(34-36): 317-319; 1972 11(44): 659-662).

5 Kovtun je autorem románů Pražská ekloga (1973) o průběhu Pražského povstání v květnu 1945 a Zprávy z Lisabonu (1979) o událostech spojených se zemětřesením v portugalském hlavním městě na sklonku 18. století. 
dření existenciální nejistoty“, „nalezení niterné rovnováhy“, ale i o „smíření s pomíjivostí všech věcí“ (Putna 2017: 316). Ačkoliv nám Kovtunovy strofy místy navozují sentimentálně cituplnou náladu, jeho poezie je hlavně umírněná, meditativně rozjímavá, plynoucí v jakémsi lyrickém bezčasí, bez agitačních výzev ke změně společenského řádu, prostoupena tlumenou obrazností a psána ve vybraném, vyšším stylu:

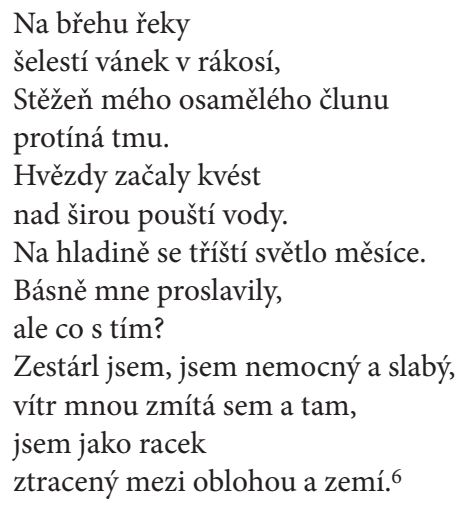

V neposlední řadě je důležité upozornit na ještě jednu charakteristickou oblast pro Kovtuna-básníka a tou je jeho schopnost vytvářet literární nápodoby. Kromě zmíněných Radostí a smutků básníka Tu Fu, parafrází na meditativně-rozjímavou poezii staré Číny, jež náš básník údajně pořídil na základě anglických a německých překladů (Salvet 1997: 113), stojí za povšimnutí jeden ze čtyř oddílů Hřbetu velryby, a sice Sentimentální dopisy, pořízené v letech 1956-1959. Tyto dopisy jsou psané formou krátkých lyrických próz a obsahem i formou navazují na sbírku Moji př́telé (1913) Jakuba Demla (1878-1961), básníka, k němuž Kovtun, jak se domnívá jeho dcera Karolina, choval vřelý vztah:

KOPŘIVO, aspoň v tom jsi dobrá, že housátka krmíš, nehledíc na to, čím jsou. Také plešatcové - hm, hm, ano, to jsem chtěl říci: upadneš-li v pokušení, abys pohrdala duší svou, vzpomeň si vždy na své jaro, kdy tvé sestry zůstávaly opatrně v zemi, čekajíce, až to bude jistější - a na toho, jenž své hosty sbírá už jen na rozcestí a za ploty. Soňo! (Deml 1989: 20)

\section{U Kovtuna čteme:}

Milé kopřivy, Rostete ještě v té chudinské uličce, kde jsem nepotkával růže, pivoňky a slunečnice, ale zato vás, diviznu a bodláky? [...] Nejvíc vás bylo pod oknem staré paní Anduly, která téměř nikdy nevycházela ze své světničky a o jejímž žalu jsme př́liš nepřemýšleli. Plazily jste se těsně podle zdí a syčely jste a my, dobrodruzi, kterým se poslední noci zdálo o Arábii a o zaklínání hadů, jsme prchali před vaším uštknutím. [...] Vaše duté zuby už nás nemohly prŕliš uškodit, protože jediná horká hodina na modrém vzduchu vysušila v žilách všechen jed. Z trávníku jsme se pak zvedali silnější než kdykoli předtím. [...] Klidně a rychle jsme pili ten škodlivý, ale omamný doušek. Ale ani přitom jsme nemysleli na starou paní Andulu a na to, zdali ona poznala východisko. (Kovtun 1995: 13)

6 Jedná se o přepsanou báseň Noční premítání v člunu ze souboru Hřbet velryby (1995: 143). 
Dlužno podotknout, že v Sentimentálních dopisech se Kovtun neomezuje pouze na svět flóry, jak se může ze záměrně zvolené apostrofy kopřiv zdát; ve snaze navodit „demlovskou" atmosféru oslovuje i další neživé subjekty (např. zrcadlo či petrolejovou lampu), které mu v emočně i existenčně obtížné životní situaci „ztělesňují dětství a skrze něž se snaží vzkř́isit jeho zavátou polohu." (Salvet 1997: 111) K obdobnému závěru dospěl i Jan Štolba (1995: 7), když poznamenal, že Kovtun se v těchto lyrizovaných prózách vrací do dětských let, resp. ke svým prožitkům z (nejspíše jihočeského?) venkova, cest, polí, krajiny.

\section{Kovtun-překladatel}

Jiří Levý (1971: 228) se domnívá, že za „vrcholný výkon Čapkova překladatelského umění bývá právem pokládáno přetlumočení Apollinaira, "přičemž pro svou domněnku následně hledá oporu - s ohledem na Čapkův výběr básníků a dosavadní tuzemskou překladatelskou tradici. Analogicky se nabízí otázka, na koho se jako překladatel zaměřil Jiří Kovtun.

Kompletní soupis jeho překladů dosud nebyl pořízený. Vzhledem ke skutečnosti, že si Kovtun žádnou personální bibliografii nevedl (přinejmenším není $\mathrm{k}$ dohledání v překladatelově pozůstalosti uložené v soukromém archivu ve správě Karoliny Kovtun) a téměř po celý život působil v exilu, jsme provedli nezbytnou rešerši s využitím následujících specializovaných databází: Česká literární bibliografie, ${ }^{7}$ Databáze českého umèleckého překladu ${ }^{8}$ a v neposlední řadě také Projekt Scriptum, ${ }^{9}$ jenž nekomerční cestou zpř́stupňuje význačné tituly českých exilových a samizdatových periodik.

Závěr z provedené rešerše zní následovně: jako překladatel byl Kovtun činný $s$ krátkodobými odmlkami v letech 1945-1989, jeho překladatelské začátky lze datovat do dob jeho vysokoškolských studií, kdy př́ležitostně publikoval své překlady v Akordu, Bloku či Vývoji; v pozdějších letech mezi jinými na stránkách Archy, Vokna a exilových periodikách jako Zápisník či: čtvrtletník pro politiku a kulturu. V nakladatelství Svědectví vyšly také jeho převody myšlenkově i jazykově náročných básníků: cyklus pětadvaceti závěrečných básní z románu Borise Pasternaka Doktor Živago (1957, č. 1990), vydaný samostatně jako Básně doktora Živaga (1959), sbírky Velká elegie (1968) Josifa Brodského a Topưrko pro Kata (1979) a Básně (1988) z pera Osipa Mandelštama. Jako překladatel je rovněž uveden pod Řečí o pravdě (1972), esejem Alexandra Solženicyna.

$Z$ výšeuvedených př̀evodů před námi vyvstává obraz překladatele a interpreta ruských literátů $v$ jejich svobodomyslných a náboženských polohách, s nimiž si na základě vlastního bytostného založení buduje niterní vztah a v nichž nachází svou překladatelskou vášeň - jsou to převážně disidenti a disidentky, básníci a básnírky, nepohodlní režimu, oběti politických procesů (mj. Alexandr Jesenin-Volpin, Jevgenij Jevtušenko, Natalja

7 Z tohoto souboru literárních bibliografí jsme zvolili: Retrospektivní bibliografii (do roku 1945), Českou literaturu v exilu (1948-1989), Bibliografii české literární vědy (od roku 1945). Dostupné z: http://clb .ucl.cas.cz (access: 21. 9. 2017).

8 Dostupné z: http://www.databaze-prekladu.cz (access: 21. 9. 2017).

9 Dostupné z: http://www.skriptum.cz (access: 21. 9. 2017). 
Gorbaněvská či Irina Ratušinská), ${ }^{10}$ kteří rovněž zabydlují - explicitně i implicitně Kovtunův lyrický svět: kupř. v básni Pozdravujte, ${ }^{11} \mathrm{v}$ jejímž popředí stojí „Jeseninova“ bříza, nebo v Dopisu do Vladivostoku, ${ }^{12}$ adresovanému Osipu Mandelštamovi. Dlužno podotknout, že svůj podíl na výběru autorů pravděpodobně má, jak uvádí i Martin C. Putna (2017: 319), Kovtunovo rodinné zázemí: vztah k ruské literatuře údajně zdědil po předcích - otec byl ruský kozák z Podkarpatské Rusi, který po bolševickém převratu prchl do Československa.

Pro porozumění Kovtunovi-překladateli v kontextu české, resp. československé translatologie, je stěžejní právě výběr ,jeho“ autorů, jenž nám nasvěcuje exilového překladatele v jiném světle, než bylo v tuzemské realitě, v podmínkách cenzury a s vytyčenými kritérii k rozeznání umělecké hodnoty, dosud zvykem. ${ }^{13}$ Kovtunův status poúnorového emigranta a člověka žijícího v souladu s křestanskými hodnotami se projevuje i v této rovině: exil umožňoval překladateli zvolit si takové texty z tehdejší ruské kultury, jejichž vydání by v bývalém Československu nebylo obhajitelné. Vybíral si to, co bylo blízké nejen jemu samotnému, ale o čem právem soudil, jak se domnívá Putna, že to „může oslovovat i exulantskou a/nebo katolickou komunitu.“ (Putna 2017: 320) Právě proto lze Kovtuna označit za nový typ českého rusisty, tj. za takového rusistu, který „ruskou kulturu obdivuje, miluje a tlumočí v jejích (proto)disidentských a/nebo (novo)křestanských polohách, aktuálních pro novou situaci české kultury.“ (ibid.) Své uvažování zakončuje výrokem, že „v generaci posrpnového exilu a disentu, do něhož se zařadilo tolik bývalých komunistů a/nebo vystudovaných rusistů, bude tento postoj daleko častější a Jiří Kovtun je „jeho dodnes nedoceněným průkopníkem.“ (ibid.)

\section{Kovtunův překlad Básní doktora Živaga}

Za významný překladatelský počin Jiřího Kovtuna považujeme Básně doktora Živaga (1959), závěrečnou kapitolu Pasternakova jediného románu. Bez tohoto „posledního velkého díla,“ jak o něm mluví Kovtun (1960: 11) v rozhovoru pro časopis Sklizeň, „by byl pohled na Pasternakovu tvorbu neúplný. “ Z cyklu pětadvaceti básní k nám promlouvá již vyzrálý, pozdní Pasternak, ${ }^{14}$ přičemž do jeho lyrického světa vstupují i náboženské motivy a témata, která se v jeho dosavadní tvorbě dosud prakticky neobjevovala. Možná

10 Ze světové literatury českému čtenáři zprostředkoval také ukázky z básnické tvorby Czesława Miłosze (spolu s bratrem Emilem), Marcela Ormoye, přebásnil strofy Juana Ramóna Jiméneze či Paula Celana.

11 „Pozdravujte / tu břízu, / ze které by se radoval / i podnapilý Sergej Jesenin, protože ochotně kojila svým mlékem / kterékoli scestné mládě // a pozdravujte / ten les v jižních Čechách, / jehož obrys byl nakreslen mým údivem. "Citováno dle Hřbet velryby (1995: 58).

12 „Děkujeme vám, pane Mandelštame, / poslal jste nám šeřík pěny v nádobě moře / a třpyt polárních lišek v noční tmě. / Udělal jste nám radost, opravdu, tu vkusnou pohlednici / si dáme na zed', / při tom světýlku na vás budeme vzpomínat. / Neurazíte-li se, / přijměte tento balíček jednoduchého pečiva / a něco na sebe. [...].“ Citováno dle Hřbet velryby (1995: 86).

13 Srov. Hrala, Milan (2003) 'Překlad z ruštiny 1945-2003', in Český překlad I (1945-2003). Praha: FF UK, 20-26; a Zahrádka, Miroslav (2005) 'Peripetie a percepce ruské literatury u nás po roce 1945', in Český překlad II (1945-2004). Praha: FF UK, 280-285.

14 Autorovou tvorbou se jako nit’ vine cesta od složitosti k prostotě. Ve svých počátcích dominovala v jeho poetice touha po novátorství a snaha vymezit se vůči dosavadním směrům, což se promítlo do jeho veršů místy až př́liš komplikovaným zpơsobem vyjadřování a složitou metaforikou. 
i právě proto básně upoutaly Kovtunovu pozornost, vezmeme-li v potaz, že žádného jiného převodu Pasternakova díla do češtiny se nezhostil.

Kovtun nebyl sám, kdo chtěl změřit své překladatelské síly na Živagově sbírce. ${ }^{15}$ Žádnému jinému překladateli se však nepodařilo převést do češtiny kompletní cyklus, zvládli nanejvýš několik vybraných básní, a proto lze s jistotou říci, že s Kovtunovým příchodem nastává v překládání básní Doktora Živaga zlom. ${ }^{16}$ Nadto má jeho překlad Pasternakových básní význam národně-kulturní: zatímco po srpnových událostech roku 1968 vydání Doktora Živaga, na němž pracoval Jan Zábrana, nepřicházelo v úvahu a k tuzemskému čtenáři se první kompletní vydání dostalo s mnoholetým zpožděním až v roce 1990, exil nabízel jiné možnosti.

Kladné přijetí literární kritikou a vzedmutý čtenářský ohlas ${ }^{17}$ jsou důkazem toho, že Kovtun byl ve své práci překladatele úspěšný. Osobité hodnocení poskytl literát Jiří Svoboda, když na stránkách Archy uvedl, že „těžko bychom hledali v českém současném básnictví - nejen v exilu, ale i ve vlasti člověka, který by hlouběji pronikl k uměleckým tvárným pramenům a inspiračním zdrojům Borise Pasternaka, jako je Jiří Kovtun. “ (Svoboda 1961: 79) Dále pokračuje, že „Básně doktora Živaga nejsou překladem, ale v ryzím slova smyslu přebásněním.“ (ibid.) Takový soud vyvolává potřebu translatologického rozboru, nicméně zmapovat, zda do překladatelského procesu Jiř́ího Kovtuna vstupuje rovněž jeho schopnost přebásňovat texty a zda se uchyluje ke stejnému výběru lexikálních prostředků jako při psaní vlastní poezie, si žádá řadu dalších šetření. Proto je na následující tvrzení třeba nahlížet jako na dílčí závěry.

Jaký je Boris Pasternak v podání Jiřího Kovtuna? Abychom tuto otázku zodpověděli, srovnejme jednu z položek živagovského cyklu, báseň Březen, s její ruskou předlouhou:

\footnotetext{
Март

Солнце греет до седьмого пота, И бушует, одурев, овраг.

Как у дюжей скотницы работа, Дело у весны кипит в руках.

Чахнет снег и болен малокровьем
В веточках бессильно синих жил.
Но дымится жизнь в хлеву коровьем,
И здоровьем пышут зубья вил.
}

Эти ночи, эти дни и ночи!

Дробь капелей к середине дня,

\author{
Březen (1959) \\ Slunce pálí, poblouzněný hukot \\ naplňuje rokli v horečce. \\ Práce vře a překypuje v rukou \\ jaru - růžolící děvečce.
}

Sníh má souchotiny, z žil mu prýští liknavá a ubohoučká krev.

Hroty vidlí se však zdravím blyští, životem a silou dme se chlév.

Tyto noci, tyto dny a př́ítmí!

Krůpěj o poledni - její chlad.

15 Pasternakův cyklus neunikl pozornosti řady renomovaných, ale i amatérských překladatelů a překladatelek: kupř. Zdeňky Bergrové, Ladislava Fikara, Ludka Kubišty nebo Jana Zábrany.

16 Před Kovtunem se mohl český čtenář seznámit kupřs s exemplářem šesti básnických převodů Ladislava Fikara ze závěrečného cyklu, jejž v témže roce rozšíril o další položku J. Zábrana svým překladem básně Svitání.

17 V jeho pozůstalosti je uloženo několik dobových dokumentů, na nichž jsou zachyceny oslavné zdravice a gratulace $\mathrm{k}$ překladu, kupř. od Ivana Jelínka, překladatele $\mathrm{z}$ němčiny a angličtiny, novináře a zpravodaje britské BBC: „Je to krásná práce. Projevil jste při ní zdravý rozum, což vedle jemného citu, jak se vždy píše v kritikách, je stejně důležité. Také vynalézavost, se kterou jste se dovedl potopit do jeho tekuté vody poesie." Vlídná slova díků Kovtunovi poslal také hlasatel a redaktor Pavel Tigrid nebo římskokatolický kněz František Planner. 
Кровельных сосулек худосочье, Ручейков бессонных болтовня!

Настежь все конюшня и коровник. Голуби в снегу клюют овес,

И всего живитель и виновник, Пахнет свежим воздухом навоз.
Povídavý potok - jeho rytmy. Chudokrevný střechýl - jeho pád.

Stáje dokořán jsou otevřeny. Holub klove oves v mokřinách, z vonné mrvy stoupá ojíněný doušek vzduchu, blahodárný pach.

Za základní princip básně, popisující březnovou přírodu a nastiňující syrový obraz venkova, lze označit personifikaci: „солнце греет“, „дело у весны кипит в руках“, „чахнет снег“, všechno zde ožívá a dynamicky narůstá již od prvního verše. Původní metrum Kovtun zachovává - pětistopý trochej, v němž se stř́́dá desetislabičný ženský akatalektický verš $s$ devítislabičným mužským katalektickým veršem. V překladu rovněž vše ožívá, avšak poněkud jinak: čteme-li jej bez znalosti originálu, působí nenuceně, má pravidelnou formu, je $\mathrm{z}$ něho cítit zdařilá práce s figurami a tropy. Jakmile si však vezmeme $\mathrm{k}$ ruce originál, zjistíme, že se překlad své předloze $\mathrm{v}$ řadě míst vzdaluje, a proto bychom mohli uvažovat - stejně jako Jiří Svoboda -, zda Kovtun Pasternaka do češtiny opravdu překládá, anebo „pouze“ přebásňuje.

Obecně lze říci, že Kovtun svým tvưrčím přístupem k původnímu textu prokazuje službu spíše básníkovi než samotnému textu. Z jeho překladatelských tendencí je výrazná snaha po větší abstraktnosti, snaha domýšlet obraz dle vlastní interpretace, oprostit se od neutrálního lexika, a naopak volit stylisticky příznaková slova. V těch místech, kde má Pasternak konkrétní slova i obrazy, naopak tíhne k abstraktním výrazům a představám. Je logické, že někdy si tímto způsobem vypomáhá kvưli rýmové shodě, jak je patrné u prvního verše třetí strofy („přítmí - „rytmy“), nebo u druhého verše čtvrté strofy („mokřinách“ - „pach“), nicméně v ostatních př́padech dle našeho soudu Kovtun poetizuje až př́liš̌: „Как у дюжей скотницы работа, / Дело у весны кипит в руках.“ јako „Práce vře a překypuje v rukou / jaru - růžolící děvečce“ nebo „Чахнет снег и болен малокровьем В веточках бессильно синих жил." př̀ložené poměrně volně, s odlišnými výrazovými prostředky jako „Sníh má souchotiny, z žil mu prýští liknavá a ubohoučká krev“. V tomto ohledu se zajímavou jeví třetí strofa, v níž se Kovtun snažil absenci slovesných vazeb vypointovat přes pomlčku: porovnáme-li Pasternakovo „Эти ночи, эти дни и ночи! / Дробь капелей к середине дня, / Кровельных сосулек худосочье“ s překladem, zjistíme, že pro Kovtunovy obrazy př́liš opory v ruské předloze nenacházíme: za tiché bubnování deštových kapek máme „krůpěj o poledni“, přibyl „chlad“, zjevně opět kvůli rýmové shodě, avšak je zajímavé, že ani o jeho rýmové dvojici (,jeho pád“) není v originále zmínka, což platí i pro velmi osobitý výraz „chudokrevný střechýl“.

Zřejmě za všemi posuny stojí forma originálu, kterou se Kovtun snaží udržet za každou cenu. Svým úsilím se logicky dopouští posunů, a proto nemůžeme vyčítat Kovtunovi, že se mnohdy liší, ale spíš by nás mělo zajímat, co stojí za jeho volbou konkrétních výrazových prostř̌edků, proč se uchyluje $\mathrm{k}$ daným překladatelským postupům. Je logické, že při překladů básnických textů nelze mluvit o absolutní doslovnosti v rovině lexikologické a stylistické, ale spíše v rovině významové - překladatelovým úkolem je nepochybně dostát srovnatelnému účinku. Každá změna by však měla být současně vyvážena nejen obligatorním rýmem, ale i ziskem, který by hodnotně kompenzoval nezbytné ztráty. 
Jak píše rusista Milan Hrala (1987: 47), překladatelskou normu po roce 1945 charakterizovala její filologická přesnost a pečlivost, snaha překladatelů pochopit jádro obsahu a ideového smyslu originálu, jazykovými prostředky zvýraznit jeho politickou aktuálnost a užitečnost. Až s nástupem generace Jana Zábrany došlo ke změně: v jeho překladech se dle Hraly (1987: 47) „projevil programový protest proti unifikaci, doslovnosti a přesnosti vyjádření v povrchové rovině [...]“, nebot’ „nová generace se orientovala na hlubší pochopení díla v jeho širších společenských a uměleckých souvislostech, na jeho výklad a dotvoření. “ Takový je i Kovtun: z provedeného rozboru lze vyvodit, že překladatel se na vybraných místech nechává strhnout svým idiolektem a vlastní představou, které podrobí vše okolo. Zobecnit tvrzení, že z takových míst k nám nepromlouvá překládaný autor, nýbrž básnická osobnost Jiř́ho Kovtuna se svébytným, charakteristickým stylem vyjadřování, prosyceným jeho citově zabarvenou lyrikou, si však žádá další analýzy, a proto jej $\mathrm{v}$ tuto chvíli nelze považovat za axiom, nicméně v př́padě básně Březen jsme k tomuto závěru dospěli.

\section{BIBLIOGRAFIE}

Debnár, Viktor A (2006) 'Čas boření, čas stavění', Literární noviny 17(14): 10.

Deml, Jakub (1989) Moji prátelé, Praha: Československý spisovatel.

Hájková, Jaroslava (1992) 'I tato chvíle je věčnost', Metropolitan 2(170): 15.

Hájková, Jaroslava (1991) 'Historie nutí sokratovské skromnosti', Studentské listy (24): 13.

Hrala, Milan (2003) 'Překlad z ruštiny 1945-2003', in Český překlad I (1945-2003), Praha: FF UK, 20-26.

Hrala, Milan (1987) Současnost uměleckého překladu, Praha: Československý spisovatel.

Kovtun, Jiří (1995) Hřbet velryby, Praha: Torst.

Kovtun, Jiř́ (1960) 'O Pasternakových Básních doktora Živaga', Sklizeň 8(9-10): 10-12.

Levý, Jiří (1971) 'Čapkovy překlady ve vývoji českého překladatelství a českého verše', in Bude literární věda exaktní vědou?, Praha: Československý spisovatel, 227-268.

Opat, Jaroslav (1991) 'Rozhovor místo doslovu', in Jiř́ Kovtun, Masarykův triumf, Praha: Odeon, 521525.

Putna, Martin C. (2017) Česká katolická literatura 1945-1989, Praha: Torst.

Salvet, Jiří (1997) 'Nostalgické volání', Host 13(4): 111-113.

Svoboda, Jiří (1961) 'Pasternak stále živý', Archa 3(3): 79-80.

Štolba, Jan (1995) 'Hvězda se obveselila ploutví', Literární noviny 6(36): 7.

Trávníček, Jiří (1995) 'Hlasy z mírna’, Tvar 6(19): 20.

Zahrádka, Miroslav (2005) 'Peripetie a percepce ruské literatury u nás po roce 1945', in Český překlad II (1945-2004), Praha: FF UK, 280-285.

\section{Elektronické zdroje}

http://www.scriptum.cz (access: 21. 9. 2017).

http://www.databaze-prekladu.cz (access: 21. 9. 2017).

http://clb.ucl.cas.cz (access: 21. 9. 2017). 


\section{PEЗЮME}

Цель этой статьи - выявить роль Иржиго Ковтуна, чешского писателя и историка, его вклад в развитие чешского переводоведения. Наша статья основана на статье «Переводы Карела Чапека в развитии чешского переводоведения и стиховедения», написанной Йиржим Левым, которая служит нашей теоретико-методологической основой. Хотя работа Иржиго Ковтуна не является обширной, его переводы имеют важное значение: в контексте его перевода «Стихи доктора Живаго», изданного издательством «Svědectví», мы попытались продемонстрировать, на чем основан метод перевода Ковтуна, и как на его творческий процесс и выбор переводимых авторов повлиял тот факт, что он сам был поэтом. Вывод заключается в том, что переводы Ковтуна точны в формальном смысле, но часто теряют первоначальный характер и вносят в переводные стихи элементы собственного поэтического идиолекта переводчика.

\section{Mgr. Lukáš Klimeš}

Ústav translatologie, Filozofická fakulta Univerzity Karlovy, Praha

lukas.klimes@ff.cuni.cz 